University of Nebraska - Lincoln

DigitalCommons@University of Nebraska - Lincoln

Mammalogy Papers: University of Nebraska

State Museum

Museum, University of Nebraska State

$11-1-1978$

\title{
An Analysis of Hair Structure and Its Phylogenetic Implications among Heteromyid Rodents
}

Jacqueline A. Homan

Texas Tech University

Hugh H. Genoways

University of Nebraska - Lincoln, h.h.genoways@gmail.com

Follow this and additional works at: https://digitalcommons.unl.edu/museummammalogy

Part of the Zoology Commons

Homan, Jacqueline A. and Genoways, Hugh H., "An Analysis of Hair Structure and Its Phylogenetic Implications among Heteromyid Rodents" (1978). Mammalogy Papers: University of Nebraska State Museum. 50.

https://digitalcommons.unl.edu/museummammalogy/50

This Article is brought to you for free and open access by the Museum, University of Nebraska State at DigitalCommons@University of Nebraska - Lincoln. It has been accepted for inclusion in Mammalogy Papers: University of Nebraska State Museum by an authorized administrator of DigitalCommons@University of Nebraska Lincoln. 


\title{
AN ANALYSIS OF HAIR STRUCTURE AND ITS PHYLOGENETIC IMPLICATIONS AMONG HETEROMYID RODENTS
}

\author{
JaCQueline A. Homan and Hugh H. Genoways
}

\begin{abstract}
Hair morphology of 36 species of the family Heteromyidae including the genera Dipodomys, Perognathus, Microdipodops, Liomys, and Heteromys was studied using both light and scanning electron microscopy. Variables investigated included length and width of hair, imbricate scale pattern, external and cross-section form of hair, and medullary characteristics. Although the hair of individual species could be characterized with detailed study, we do not believe that hair structure will be of value in evolutionary studies of this group below the generic level. The overhair of heteromyid rodents falls into two morphological types-hair which is round to oval in outline and hair which has a trough along the dorsal surface. Hair of the first type is found in most perognathines, and all members of the genera Dipodomys and Microdipodops. Troughed hairs are found in all chaetodipines, Liomys, and Heteromys and the perognathines, $P$. ampulus and $P$. formosus.
\end{abstract}

As a taxonomic character, hair structure has been used primarily in studies of bats (Cole, 1924; Nason, 1948; Benedict, 1957; Miles, 1965). These authors concluded that hair characters were of no value below the generic level. However numerous keys have been written for mammals, which are based solely upon hair characteristics (Toldt, 1935; Mathiak, 1938; Mayer, 1952; Moore et al., 1974). Such keys have been used in regional surveys and investigations of food habits (Day, 1966, 1968; Stains, 1958; Williams, 1938), forensic medicine (Hausman, 1944; Stoves, 1942), and archaeology (Douglas, 1965; Appleyard and Wildman, 1969). Short (1978) has recently studied the cuticular scale patterns of the hair of a variety of species of mammals. He concludes that species could not be characterized solely on the basis of cuticular scale pattern but they could be if a variety of characters of the hairs were used. The thermoregulatory aspects of mammalian hair covering have been studied by several workers (Herrington, 1951; Carpenter, 1966; Ghobrial, 1970).

All hair is comprised of three major portions-cuticle, cortex, and medulla. The cuticle or covering of individual hairs is made up of overlapping scales, the distal edges of which are free. The patterns made by these scales have been classified by Hausman (1920) into two types-coronal (scales surrounding the hair shaft) and imbricate (scales not surrounding the hair shaft). The shape of the individual scale is also an important feature. An inverse relationship between the width of a hair and the proximodistal length of each scale has been reported by Hausman (1930) and Noback (1952). The primary function of the cuticle is protection of the hair (Rudall, 1941; Azzola and Shurmann, 1969). After treatment with trypsin, the structural elements of the cuticle are found to be a network of what appears to be fibers of various widths, which appear randomly oriented (Lundgren and Ward, 1963). Another structural component of the cuticle can be seen in some overlapping scales where small projections from the underscale protrude into the overlying scale (Rogers, 1959a). The development of scanning electron microscopy and other techniques have allowed detailed study of the ultrastructure of cuticular scales. Each scale is composed of an epicuticle, an exocuticle, and an endocuticle. The outermost layer, the epicuticle, has received much attention (Haly et al., 1970; Bradbury and Leeder, 1970; King and Bradbury, 1968; Leeder and Bradbury, 1968). This layer influences the surface properties of wool, as well as probably other types of hair, including wettability and frictional characteristics. 
The middle layer of a hair shaft, the cortex, is made up of fusiform or spindle-shaped cells, which interdigitate with each other along the long axis of the shaft. In some kinds of hair there are air spaces or fusi between the cells (Hausman, 1932). Each cell contains a nucleus and pigment granules. As keratinization takes place in a growing hair, the cytoplasm is replaced by fibers of protein (alfakeratin). A keratinized cortical cell contains rounded subunits (macrofibrils) 3,000 $\AA$ in width. Within each of these units are still smaller units (microfibrils) 60-80 $\AA$, which are separated and delineated by thin layers of dense matrix (Anderson and Lyeder, 1971; Anderson and Lipson, 1970; Rogers, 1959a, 1959b). A microfibril contains "protofibrils" $20 \AA$ wide and is composed of smaller filaments, possibly single protein molecules (Johnson and Speakman, 1965). Another division of the cortex is that of the ortho- and paracortex in some wools. Chapman and Bradbury (1968) concluded that the differences between the two areas are based on (1) the configuration of the microfibrils, (2) the microfibril to matrix ratios, and (3) possible variation in amino acid sequences in the two areas.

The central portion of the hair shaft, the medulla, is made up of cells of various shapes, which are often interspaced with air pockets. The presence and patterns of these cells have been used to distinguish various kinds of hair (Hausman, 1920, 1944; Dearborn, 1939; Day, 1966; Mayer, 1952). Bradbury and O'Shea (1969) analyzed amino acid components of the medulla in various monotremes, marsupials, and placentals and discovered remarkable similarity of composition in all medullas. Pigment is normally concentrated in the medulla cell, but may be lacking entirely.

The present study provides data on various aspects of the morphology of the hair of members of the rodent family Heteromyidae using both light and scanning electron microscopy. Heteromyid rodents form a unique and autochthonous component of the North American mammalian fauna. Systematic studies of the various genera of the Heteromyidae include the following: Dipodomys (Burt, 1936; Lidicker, 1962; Lackey, 1967; Stock, 1974); Perognathus (Patton, 1967a, 1967b); Microdipodops (Hall, 1941); Liomys (Genoways, 1973); Heteromys (Goldman, 1911). None of these studies utilized structure of hair as a systematic character. Variables investigated in the present study included length and width of hair (as defined by Mayer, 1952), imbricate scale pattern (Hausman, 1920; Miles, 1965), and medullary characteristics (Hausman, 1920; Mayer, 1952).

\section{Materials AND MethodS}

Thirty-six species from the family Heteromyidae were chosen for study. Among these species are representatives of all subfamilies, genera, subgenera, and species groups recognized by Hall and Kelson (1959) and Genoways (1973).

A number of authors stress the use of underfur in studies of hair (Hausman, 1920, 1930; Cole, 1924). Others have preferred the use of the guard hair (Williams, 1938; Stoves, 1942; Mayer, 1952; Stains, 1958). The overhair or guard hair was used in the present study because this type is far more abundant than underfur in most heteromyids (Williams, 1938) and because guard hair is much more regular in shape and easier to work with than the fine underhair.

Hair samples were obtained from museum specimens and were taken from an area of the dorsum at the level of the scapulae. Additional samples were taken from the rump for comparison as well as to characterize the so-called spines prevalent in some species. A dissecting needle was used to draw the hair toward the head (against the normal grain), exposing a distinct line of fur. Samples were taken along this line with curved forceps with fine tips. Care was taken to pluck the hairs close to the skin to insure that the base of each hair was included in the samples. In this manner one or two samples provided enough hair for the study, but in no way altered or damaged the specimen. Where possible, hair was taken from specimens collected soon after the spring molt. Hair samples were labeled and stored in one-dram vials with plastic caps until needed. 
A preliminary series of scanning electron micrographs revealed the presence of a trough or depression along the dorsal surfaces of hair of certain species of Perognathus. Consequently, we thought a study of hair impressions in nail polish might reveal not only the scale patterns, but perhaps also the presence and extent of the trough. A modification of Weingart's (1973) technique was employed. A thin layer of inexpensive clear nail polish was spread evenly on a glass microscope slide and allowed to dry for at least $1 \mathrm{~h}$. A second coat, which needed at least $3 \mathrm{~h}$ to dry sufficiently, was applied to the slide for study of the coarse hair of Liomys and Heteromys. Hair was washed in acetone and placed between the coated surfaces of two slides. The slides were then placed between two wooden blocks and compressed with C-clamps for up to $24 \mathrm{~h}$. The best impressions were obtained when the clamps and blocks were undisturbed; bumping the apparatus or tightening the clamps often blurred the impressions. Photographs of the base, midsection, and tip of each hair were taken on a Leitz-Wetzlar Ortholux microscope at 500 $\times$ magnifications.

Because the scale impression technique failed to give complete information on the extent of troughs in the perognathines, we used the scanning electron microscope to explore this feature. This technique was also used to elucidate any peculiarities of the surface structure of the hair, which were not seen with light microscopy. Ten to 12 hairs, including a few from the rump, were cleaned in acetone, dried, and mounted on double-sided tape on metal stubs. They were then coated with gold in a vacuum evaporator. Each sample was examined with a Kent-Cambridge S4-10 scanning electron microscope (SEM). All hair was observed carefully before representative photographs were taken. Coated samples were stored in small, dust-proof boxes for future reference.

Because of some discrepancies in our observations between light and scanning microscopy, and to aid in the study of medullary patterns and cortex-medulla relationships, cross sections of the hair of all species were made. Several hairs of each species were embedded in Spurr's plastic (Spurr, 1969; see also Mathiak, 1938, and Williams, 1938, for other methods of sectioning). Small plastic boats were used for embedding; only a thin layer of the plastic was necessary. We found that hair was never as well infiltrated as softer tissue would be by the medium; therefore, the hair was placed directly into Spurr's plastic after cleaning in ethanol. Sections through the middle of the hair shafts were cut at one to five microns on an LKB Ultratome III microtome, utilizing glass knives. Some sections were treated with Richardson's stain, but this proved unsatisfactory because many details became too obscure to photograph. Photographs were taken through immersion oil under a cover slip.

In order to isolate various cell components of hair (especially cortical cells), a few hairs from each species were boiled gently in concentrated sodium hydroxide on a drop slide (Hausman, 1932). The cells of the hair were teased apart with fine needles and mounted on clean, glass slides in water or immersion oil for study.

Whole-mounts were prepared by placing several individual hairs in Permount under a cover slip on a clean slide. These slides were placed in a $40^{\circ} \mathrm{C}$ oven overnight to dry; this procedure drives out any air bubbles formed when mounting cover slips. Each sample was examined with a Leitz Dialux microscope at various magnifications. Drawings and measurements were taken from three to five hairs. Drawings were made with the aid of a Leitz drawing tube. Average width and maximum and minimum lengths were recorded. Medulla patterns were noted and drawn or photographed for comparison.

\section{ReSULTS}

Heteromyids, like most mammals, possess hair, which has imbricate cuticular scales. Individual scales are flattened (Fig. 4a). An inverse relationship between hair width and scale length holds true for the most part among the species in this group. Also, only one layer of scales appears to be present, unlike other groups of mammals such as carnivores (Stoves, 1944; Rudall, 1941).

The cortex of hair of heteromyid rodents varies in width and pigmentation (see the species accounts). Some overhairs have cortical cells with small protruberances (trabeculae) which Bradbury and O'Shea (1969) believe to separate the cells of the central medulla from one another. Cortical cells isolated by heating the hair in sulfuric acid showed the same spindle-shaped form as those described by Hausman (1932). Cortical 
cells from hair of Liomys and Heteromys were found to be several times larger (especially in the trough) than those of Perognathus, Microdipodops, and Dipodomys.

Medulla cells and patterns in the heteromyids show a great variety of forms, but all are compound (Hausman, 1920). Cells range in shape from round to flattened or branching; patterns are discussed under each account (Figs. 2, 6). Most of the pigment of the hair is concentrated in this region in all species examined.

Several authors have published photographs or drawings of cross sections of various kinds of mammal hair in which a concavity is present (Mathiak, 1938; Williams, 1938; Dearborn, 1939; Stoves, 1944; Day, 1966; Kozhukhovskaya, 1969; Moore et al., 1974). The study of sections of the hair of several groups of heteromyids revealed this concavity to be a trough along the upper surface of the hair shaft. Of the species selected for study, most perognathines, both species of Microdipodops, and all Dipodomys lack the trough, whereas Perognathus amplus, $P$. formosus, all chaetodipines, and all heteromyines have the trough. This feature is macroscopically distinguishable in members of the latter subfamily.

Among the species of Perognathus with a trough, the scale pattern inside the trough is virtually identical to that of the ventral surface of the hair (imbricate, flattened). On the other hand, all Liomys and Heteromys examined exhibited longitudinal rather than horizontal lines in the troughs. These were first believed to be a variation in the scale pattern (Figs. 7 upper right, lower left; 10 upper left), but further investigation with the SEM revealed normal scales overlying a series of what appear to be longitudinal ridges (cortical cells; Fig. 7 lower left, lower right). In the region of the trough the cortical cells are apparently large and sculptured, thus giving the appearance of longitudinal scales in nail polish impressions and under lower magnifications on the SEM. The area of the trough is normally lacking in any pigmentation in hair of Liomys and Heteromys.

The narrow vertical striations on the cuticular scales seen in many SEM photographs (Figs. 4 upper left, lower right; 7 upper left; and others) are possibly the result of the pattern of the fusiform cortical cells showing through the thin cuticular scales, which closely overlay them. Another possibility is that during the formation and growth of the hair but before keratinization is completed, the surface of the cuticle becomes scored by the tissue of the follicle. In any case, these striations are seen in all species examined with SEM, and no taxonomic significance should be attached to them.

Details of each structural component of the hair are given in the accounts below. In all cases the hair taken from the rump (spines) was found to have the same qualitative characters (presence or absence of the trough and the patterns of the medulla and scales) as that from the shoulders. Only hair from the shoulder region was measured for Table 1. Lengths are given before widths in parentheses in each account; all measurements are in millimeters.

\section{SPECIES ACCOUNTS}

\section{Subfamily Perognathinae}

\section{Genus Perognathus}

Among the members of the genus Perognathus, the hair is of two basic typesstraight, rather long overhair and a thin underfur of short, often slightly curved hairs. The two subgenera differ in that only two species of Perognathus show a trough, whereas all species of Chaetodipus possess troughs on the dorsal hair surface.

\section{Subgenus Perognathus}

The hairs of species in this subgenus are relatively narrow and are the shortest of all species in the family Heteromyidae. Bases, shafts, and tips vary slightly in config- 

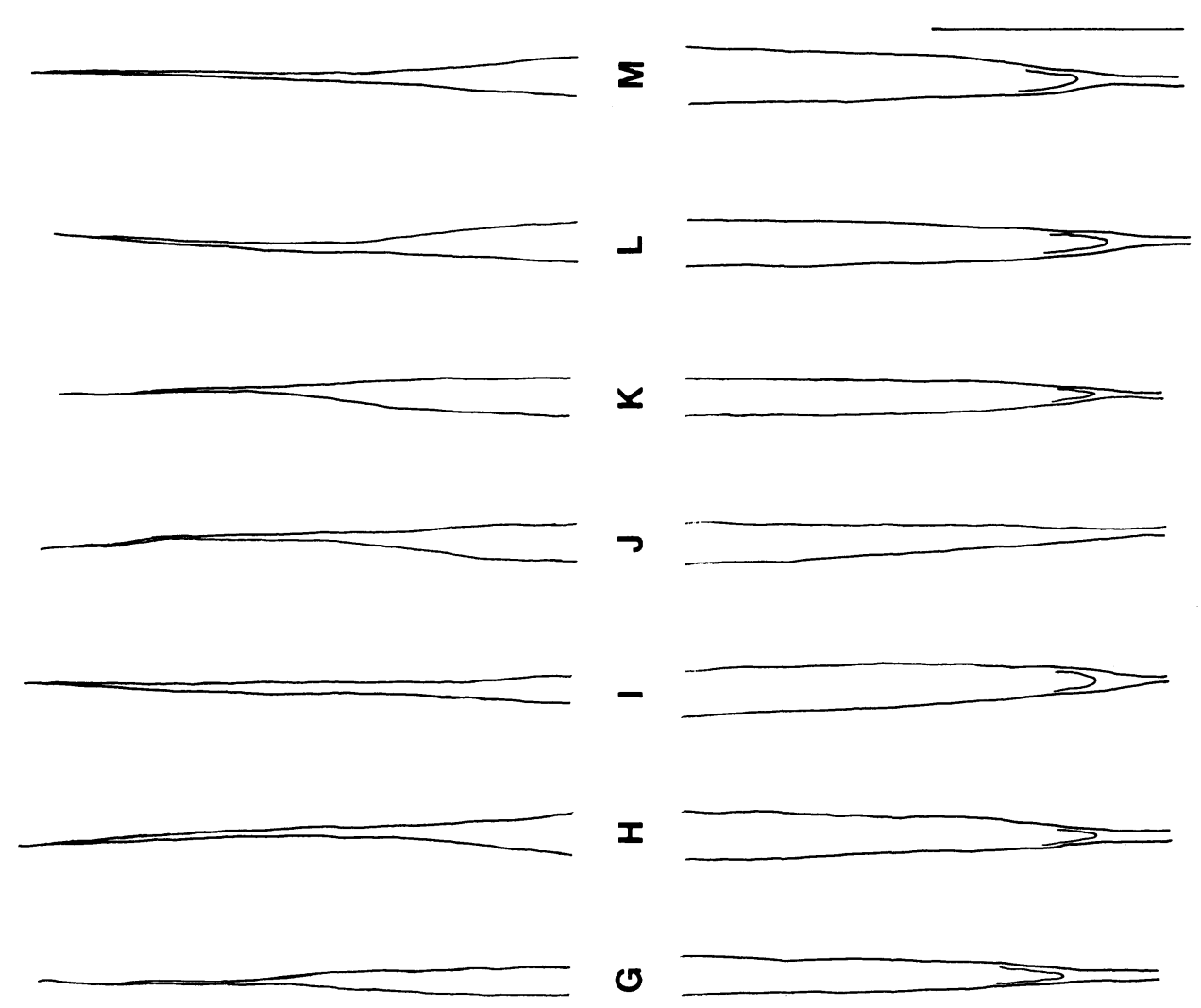

ᄂ

ш

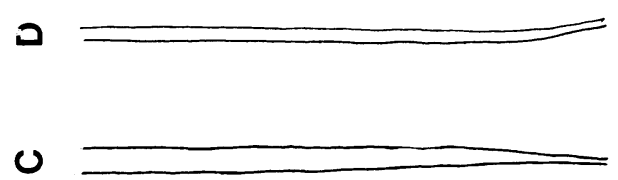

$\boldsymbol{m}$

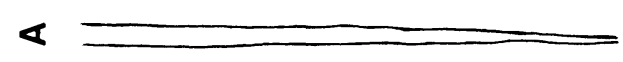



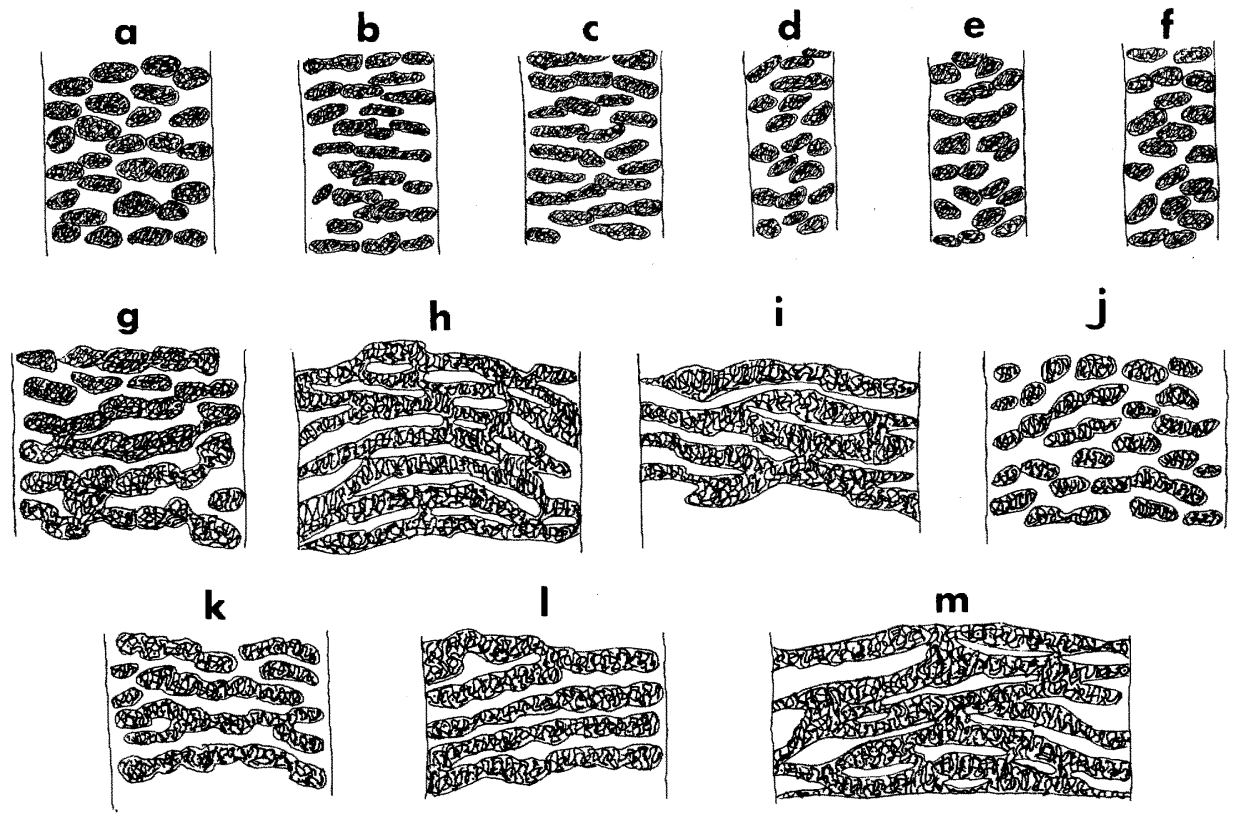

FIG. 2.-Camera lucida drawings of medulla cell patterns. The amount of pigment in medulla cells varies; those shown here indicate dense pigmentation for clarity in illustration. a) Perognathus amplus, b) P. fasciatus, c) P. flavescens, d) P. flavus, e) P. formosus, f) P. longimembris, g) P. baileyi, h) P. californicus, i) P. hispidus, j) P. intermedius, k) P. nelsoni, l) P. penicillatus, m) P. spinatus. Scale is $0.1 \mathrm{~mm}$ long.

uration. In cross section, hairs are generally oval to flattened; however, hairs of both Perognathus amplus and $P$. formosus have a dorsal trough. Medulla cells vary and are either flattened, oval, or rounded (see Figs. $1-4$ and Table 1).

Perognathus amplus.-Relatively long and wide for the subgenus (7.7 by $0.040-$ 0.060). Base and shaft straight; tip tapers abruptly to fine point. Hair flattened in cross section, seemingly with tiny ridges on dorsal surface; weak trough present, unlike most other species of subgenus. Medulla cells rounded to oval; maximum of four across, in irregular rows. USNM 212,781; Congress Jct., Arizona, 21 June 1916.

Perognathus fasciatus.-Short, broad hair (5.4 by 0.050). Base usually straight; shaft flares rapidly; tip tapers gradually. Oval in cross section. Medulla cells oval to flattened; maximum of three across, in irregular rows. USNM 202,095; Crosby, North Dakota, 24 July 1913.

Perognathus flavescens.-Average length but somewhat wide for subgenus $(6.2$ by 0.050). Base straight; shaft widens rapidly; tip tapers gradually. Oval in cross section. Medulla cells flattened; three across, in irregular rows. TTU 28,510; 5 mi S Kearney Co., Nebraska, 15 August 1972.

Perognathus flavus.-Very short, narrowest for subgenus (5.4 by $0.020-0.040)$. Base usually curved; shaft not distinct from base; tip tapers rather abruptly. Oval in cross

Fig. 1.-Camera lucida drawings of the bases and tips of hair from Perognathus (A-F subgenus Perognathus, G-M subgenus Chaetodipus). A) P. amplus, B) P. fasciatus, C) P. flavescens, D) P. flavus, E) $P$. formosus, F) $P$. longimembris, G) P. baileyi, H) P. californicus, I) $P$. hispidus, J) $P$. intermedius, K) P. nelsoni, L) P. penicillatus, M) P. spinatus. Scale is $0.5 \mathrm{~mm}$ long. 
TABLE 1.-Length and width (in millimeters) of hairs of heteromyid rodents.

\begin{tabular}{|c|c|c|}
\hline & Length & Width \\
\hline Taxa & Mean (Range) (Number) & Range (Number) \\
\hline \multicolumn{3}{|l|}{ Sf. Perognathinae } \\
\hline \multicolumn{3}{|l|}{$\begin{array}{l}\text { G. Perognathus } \\
\quad \text { (Perognathus) }\end{array}$} \\
\hline P. amplus & $7.7(7.2-8.5)(5)$ & $.040-.060(4)$ \\
\hline P. fasciatus & $5.4(4.9-5.7)(4)$ & $.050(4)$ \\
\hline P. flavescens & $6.2(5.8-6.6)(5)$ & $.050(5)$ \\
\hline P. flavus & $5.4(5.2-5.5)(5)$ & $.020-.040(5)$ \\
\hline P. formosus & $7.6(7.3-8.0)(5)$ & $.035-.040(5)$ \\
\hline P. longimembris & $8.6(8.3-8.8)(4)$ & $.032-.035(4)$ \\
\hline \multicolumn{3}{|l|}{$\begin{array}{l}\text { G. Perognathus } \\
\text { (Chaetodipus) }\end{array}$} \\
\hline P. baileyi & $9.5(9.0-9.8)(5)$ & $.070-.100(5)$ \\
\hline P. californicus & $8.4(7.6-9.6)(5)$ & $.085-.100(5)$ \\
\hline P. hispidus & $8.7(7.8-9.1)(5)$ & $.070-.100(5)$ \\
\hline P. intermedius & $9.1(8.5-9.5)(5)$ & $.080-.090(5)$ \\
\hline P. nelsoni & $6.5(6.3-6.7)(5)$ & $.070-.090(5)$ \\
\hline P. penicillatus & $8.5(8.0-8.9)(5)$ & $.080-.100(5)$ \\
\hline P. spinatus & $9.8(9.7-10.0)(3)$ & $.120-.140(3)$ \\
\hline \multicolumn{3}{|l|}{ G. Microdipodops } \\
\hline M. megacephalus & $12.7(12.3-13.0)(3)$ & $.010-.020(3)$ \\
\hline M. pallidus & $13.4(12.4-13.8)(4)$ & $.020-.040(4)$ \\
\hline \multicolumn{3}{|l|}{ Sf. Dipomyinae } \\
\hline \multicolumn{3}{|l|}{ G. Dipodomys } \\
\hline D. agilis & $13.5(12.5-14.9)(5)$ & $.030-.040(5)$ \\
\hline D. deserti & $19.1(18.5-20.6)(4)$ & $.030-.048(4)$ \\
\hline D. elator & $12.5(11.4-13.5)(4)$ & $.030-.040(4)$ \\
\hline D. elephantinus & $14.5(14.0-15.3)(5)$ & $.030(5)$ \\
\hline D. heermani & $12.2(11.5-12.9)(5)$ & $.030-.040(4)$ \\
\hline D. merriami & $13.6(13.3-14.0)(5)$ & $.040-.047(5)$ \\
\hline D. microps & $13.6(13.5-13.7)(3)$ & $.030-.040(3)$ \\
\hline D. ordii & $11.3(11.0-11.5)(4)$ & $.030-.050(4)$ \\
\hline D. panamintinus & $12.6(12.1-13.1)(5)$ & $.030(5)$ \\
\hline D. phillipsii & $11.1(9.9-12.0)(5)$ & $.030-.040(5)$ \\
\hline D. spectabilis & $15.3(14.5-16.0)(4)$ & $.035-.045(5)$ \\
\hline D. stephensi & $11.1(8.4-15.5)(5)$ & $.020-.030(5)$ \\
\hline \multicolumn{3}{|l|}{ Sf. Heteromyinae } \\
\hline \multicolumn{3}{|l|}{ G. Liomys } \\
\hline L. irroratus & $12.3(11.9-12.8)(5)$ & $.330(5)$ \\
\hline L. pictus & $9.9(9.0-10.7)(4)$ & $.190-.250(4)$ \\
\hline L. salvini & $11.6(11.2-11.9)(3)$ & $.350-.380(3)$ \\
\hline \multicolumn{3}{|l|}{ G. Heteromys } \\
\hline H. anomalus & $11.7(11.4-11.9)(5)$ & $.300-.350(5)$ \\
\hline H. australis & $9.4(9.0-0.9)(4)$ & $.190-.260(4)$ \\
\hline H. desmarestianus & $11.0(10.8-11.1)(3)$ & $.120-.160(3)$ \\
\hline H. gaumeri & $13.3(12.5-14.0)(3)$ & $.260-.370(3)$ \\
\hline H. longicaudatus & $11.9(11.6-12.6)(3)$ & $.310-.360(3)$ \\
\hline H. nelsoni & $12.2(11.6-13.0)(3)$ & $.100-.120(3)$ \\
\hline
\end{tabular}

section, but more rounded than in P. flavescens. Medulla with three oval to round cells in irregular rows. TTU 654; 3 mi SW Post, Garza Co., Texas, 20 July 1963.

Perognathus formosus.-Relatively long, medium width for subgenus ( 7.6 by 0.035 0.040). Bases straight or slightly curved; tip tapers gradually. Flattened in cross section; distinct trough with well-developed ridges on dorsal surface as in the chaeto- 

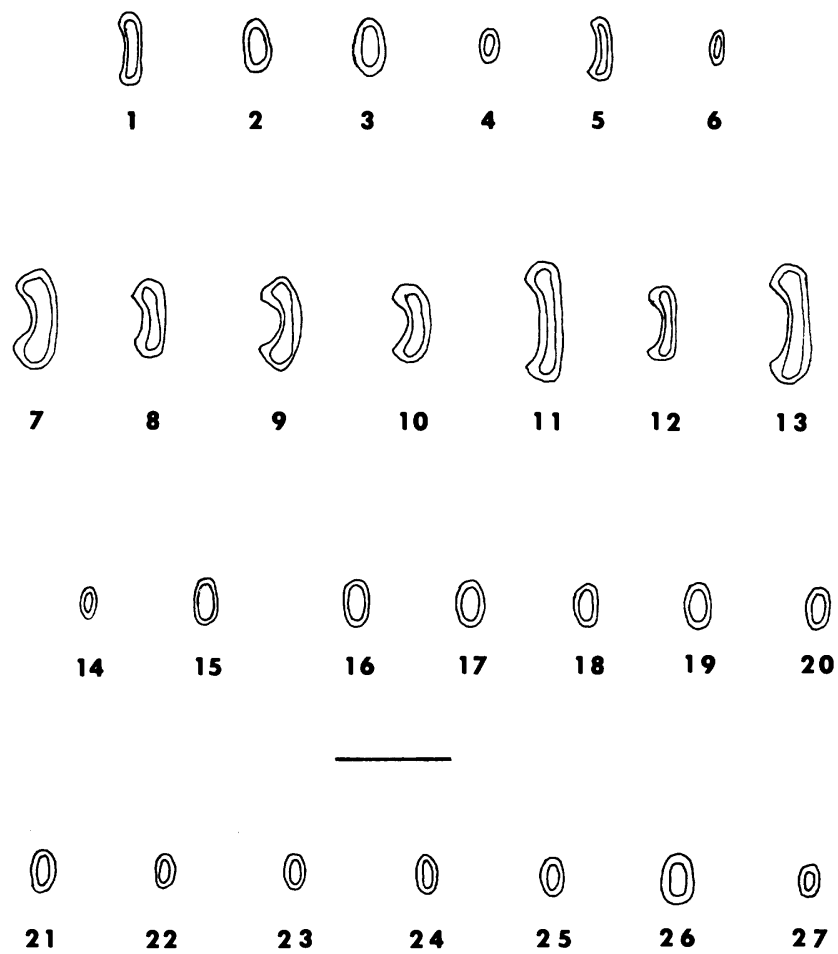

Fig. 3.-Camera lucida drawings of hair cross sections. The outline represents the cuticle, the space between the two lines, the cortex, and the inner line the outer boundary of the medulla. 1) Perognathus amplus, 2) $P$. fasciatus, 3) $P$. flavescens, 4) $P$. flavus, 5) $P$. formosus, 6) $P$. longimembris, 7) $P$. baileyi, 8) $P$. californicus, 9) $P$. hispidus, 10) $P$. intermedius, 11) $P$. nelsoni, 12) P. penicillatus, 13) P. spinatus, 14) Microdipodops megacephalus, 15) M. pallidus, 16) Dipodomys agilis, 17) D. deserti, 18) D. elator, 19) D. elephantinus, 20) D. heermani, 21) D. merriami, 22) D. microps, 23) D. ordii, 24) D. panamintinus, 25) D. phillipsii, 26) D. spectabilis, 27) D. stephensi. Scale is $0.1 \mathrm{~mm}$ long.

dipines. Medulla cells rounded to flattened; three to four across, in slanting, often irregular rows. USNM 263,158; $12 \mathrm{mi} \mathrm{N}$ Wolf Hole, Arizona, 3,500 ft., 11 August 1937.

Perognathus longimembris.-Longest but relatively narrow for subgenus ( 8.6 by 0.032-0.035). Base straight or curved; shaft widens gradually; tip tapers gradually. Flattened-oval in cross section. Medulla cells rounded to oval, two to three across, in irregular rows. USNM 78,226; Flowing Springs, Nevada, 30 May 1896.

\section{Subgenus Chaetodipus}

The hairs of species in this subgenus are short to medium in length, but relatively wide for the family Heteromyidae. The bases, shafts, and tips are all straight. Bases flare rapidly in all species except $P$. intermedius, and tips taper abruptly in all species except $P$. californicus. Troughs are always present, but vary from wide and shallow in most species to deep in $P$. baileyi and $P$. hispidus. The medulla varies from five to seven oval cells in rows in most species to the branching or fused, flattened cells observed in $P$. californicus, $P$. hispidus, and P. spinatus (see Figs. $1-4$, and Table 1). There are usually two to three conspicuous, dark medullary cells at the bases of the troughs. 


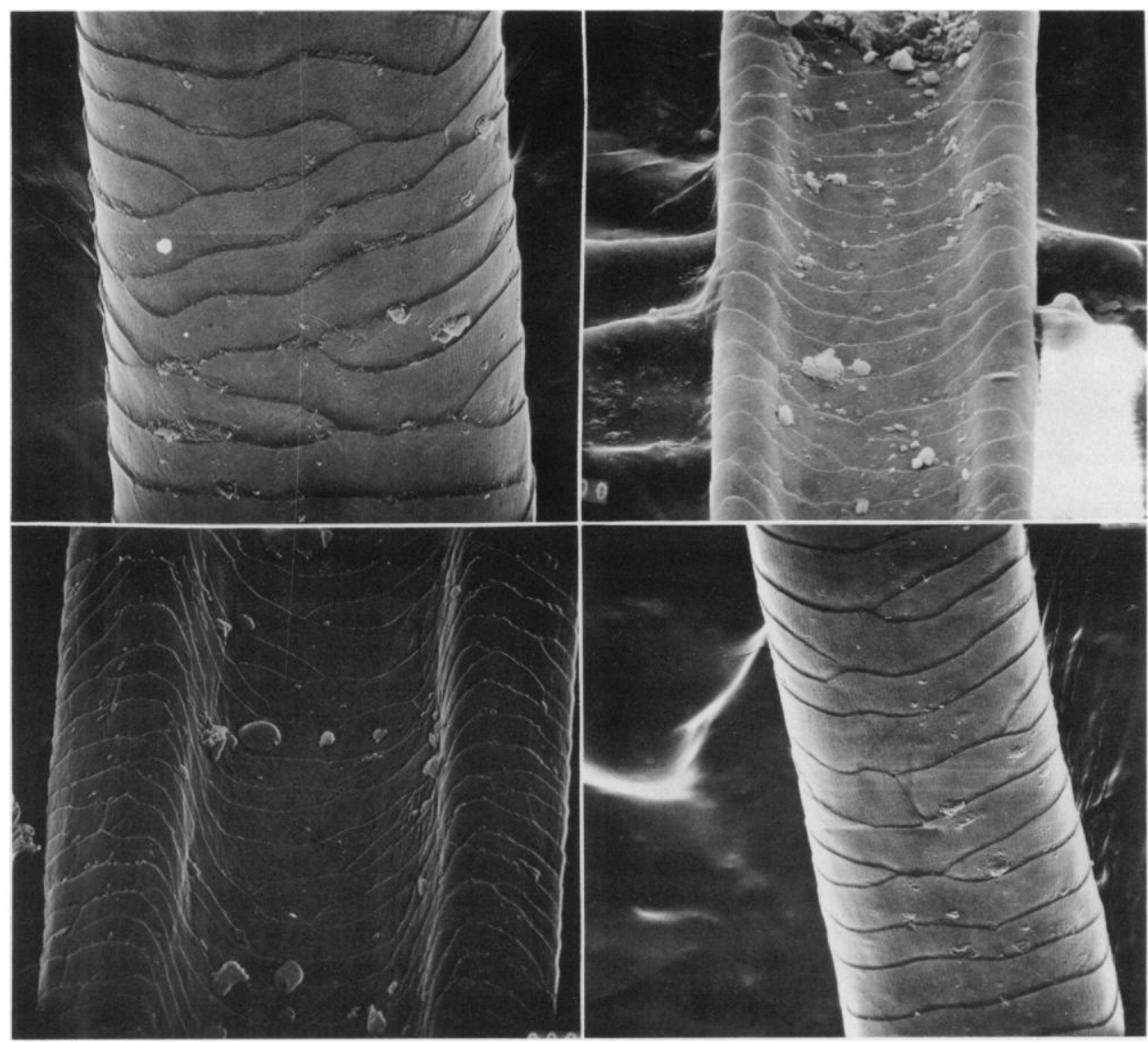

FIG. 4.-Upper left, SEM photograph of Perognathus flavus (hair approximately $.030 \mathrm{~mm}$ wide) illustrating typical flattened, imbricate scale pattern. Note also the fine vertical striations in the individual scales. See text for explanation. Upper right, $P$. formosus overhair (hair approximately 0.35 wide) showing weakly developed trough, but with typical scale pattern. Lower left, SEM photograph of $P$. hispidus overhair (hair approximately .085 wide) with relatively deep trough and less rounded ridges. Lower right, SEM photograph of Microdipodops megacephalus overhair (hair approximately $.015 \mathrm{~mm}$ wide) also indicating imbricate scale pattern. Compare to Fig. 7 upper left and Fig. 10 lower left.

Perognathus baileyi.-Relatively long, medium width for subgenus ( 9.5 by $0.070-$ 0.100). Base widens rapidly to broad shaft; tip tapers abruptly; constricted tip usually darker than remainder of hair owing to pigment granules in cortex. Cross section indicates a deep trough with high, sharply defined ridges. Medulla cells flattened to oval; five to six across, some connecting in irregular rows. USNM 212,142; Cazador Spr. (S face Nantan Plateau), San Carlos Indian Reservation, Arizona, 4,000 ft., 10 May 1916.

Perognathus californicus.-Medium in length, relatively wide for subgenus (8.4 by 0.085-0.100). Base flares rapidly to straight shaft; tip abrupt. Trough in cross section appears relatively shallow; ridges distinct. Medulla cells fused and branching. USNM 69,439; Bear Valley, San Benito Co., California, 26 June 1894.

Perognathus hispidus.-Medium in length and in width for subgenus (8.7 by 0.070 0.100). Base flares rapidly to wide, straight shaft; tip tapers gradually. Cross section 
shows relatively wide, deep trough. Medulla cell pattern indistinct; cells fused and branched. TTU 644; 3 mi S New Home, Lynn Co., Texas, 26 September 1962.

Perognathus intermedius. - Long and relatively narrow ( 9.1 by $0.080-0.090)$ for subgenus. Base narrow, unlike others in group; tip tapers abruptly. Dark cells at base of trough greater in number than others but base of trough is not as obvious. Trough relatively wide and shallow; ridges not peaked as acutely as in previous species. Medulla with up to nine round to oval cells across, in irregular rows; no fusion of cells. TTU 12,240; 5-10 mi W Carrizozo (Lava Bed), Lincoln Co., New Mexico, October 1970.

Perognathus nelsoni.-Shortest, but medium in width (6.5 by $0.070-0.090$ ) for subgenus. Base flares rapidly; shaft straight; tip abrupt. Trough in cross section shallow and wide. Medulla with five to six oval to flattened cells across; rows irregular with some fusion of cells. TTU 2041; 2 mi NW Ft. Davis, Jeff Davis Co., Texas, 29 March 1965.

Perognathus penicillatus.- Relatively long and wide ( 8.5 by $0.080-0.100$ ) for subgenus. Base flares evenly to wide shaft; tip abrupt. Trough shallow but wide; ridges less distinct than in other species. Medulla with five to seven fused cells across; rows branching. TTU 2598; 5 mi NW Headquarters, Aqua Fria Ranch, Brewster Co., Texas, 9 April 1966.

Perognathus spinatus.-Longest and widest (9.8 by $0.120-0.140)$ of subgenus. Base flares to broad shaft; tip abrupt. Cross section indicates wide trough with sharp ridges. Medulla commonly branching as in californicus and hispidus, or with distinct cells as in baileyi. USNM 71,764; San Jose del Cabo, Baja California, 6 April 1895.

\section{Genus Microdipodops}

The hair of both species of Microdipodops examined is long and slightly curved. There is no obvious distinction between the overhair and underfur. Although the lengths and widths differ slightly (megacephalus is shorter and narrower than palli$d u s)$, the two species are very similar. No trough is present in either species. The pigment in the medulla shows the most distinguishing character between the two. Refer to Figs. 3-7 and Table 1.

Microdipodops megacephalus.-Shorter and half as wide $(12.7$ by $0.010-0.020)$ as pallidus. Base and tip taper gradually; shaft slightly curved. Cross sections oval. Medulla cells rounded, not connected, with a fairly regular pattern of a row of two cells across alternating with one cell (as in five spots on a die; see also Haitlinger, 1967, Fig. 1-Apodemus sylvaticus). Cells closer together in the shaft than in pallidus. TTU 2233; 6 mi N, 1 mi W Fish Lake, Nye Co., Nevada, 12 July 1965.

Microdipodops pallidus.-Longer of the two species and wider (13.4 by 0.020 0.040). Base and tip gradual; shaft slender, curved. Cross section oval. Rounded to oval medulla cells appear connected but pigment localized to small rounded area in the center of cells; pattern as on five spots on die, similar to megacephalus. USNM 246,007; 7 mi NW Fallon, Nevada, 15 May 1925.

\section{Subfamily Dipodomyinae}

Hair of the species of this subfamily is very long and narrow for the Heteromyidae; it is smooth, unlike the coarse hair seen in some chaetodipines and heteromyines. No obvious underfur layer is present. The hairs are untroughed.

\section{Genus Dipodomys}

The base of hairs are often wide compared to the shafts. Cross sections are all oval in the species examined. Medulla cell patterns vary slightly; there is more consistency than seen in previous groups. Cells are usually rounded to oval in shape. See Figs. 3, 5-7 and Table 1 . 

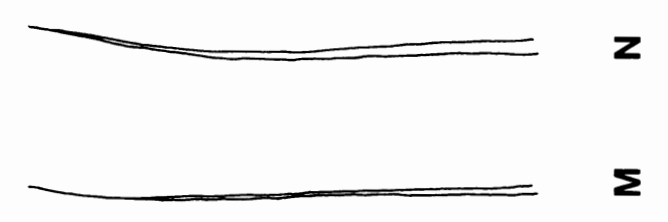

$\Sigma$
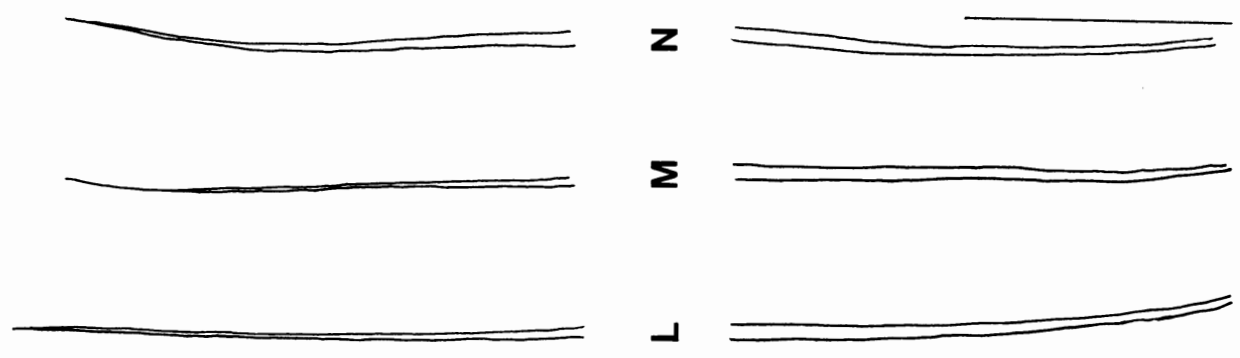

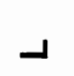

$x$
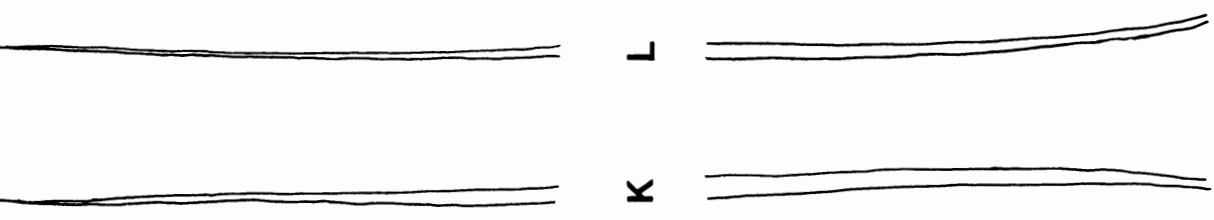

\section{$\underline{-}$}

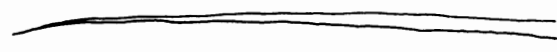

$$
I
$$

$\circlearrowleft$

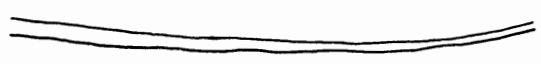

u
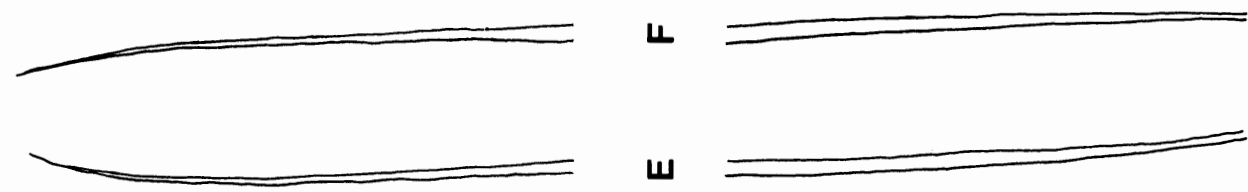

\section{山}

อ

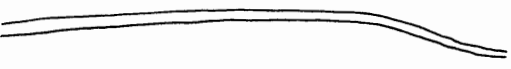

0

$\boldsymbol{\infty}$

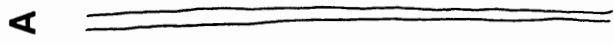



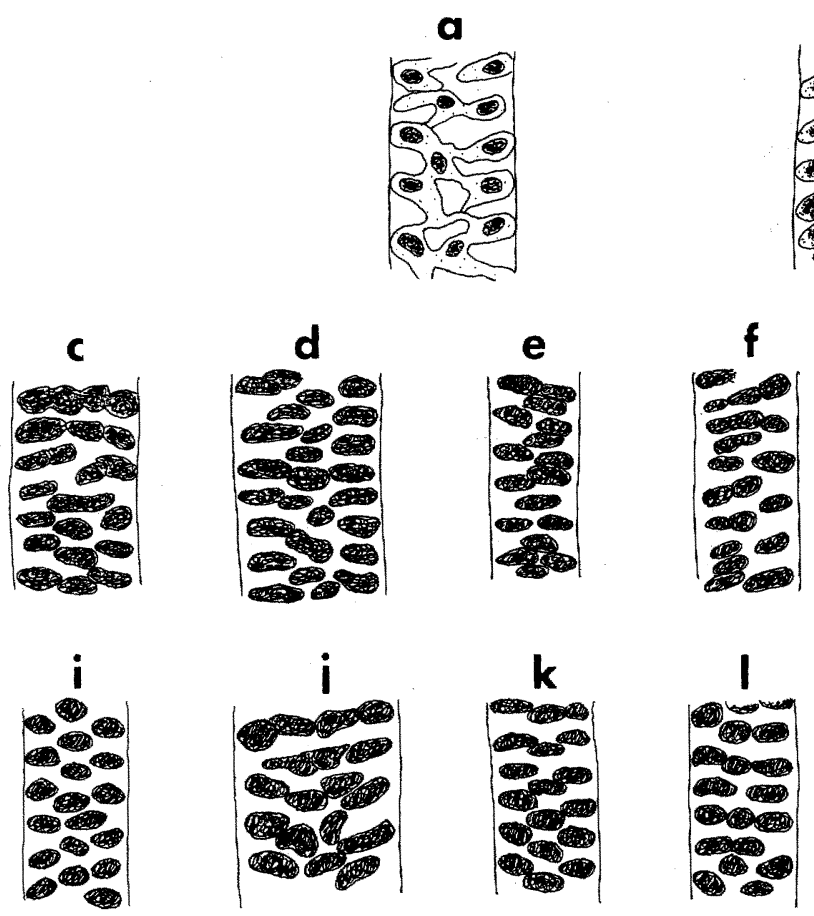
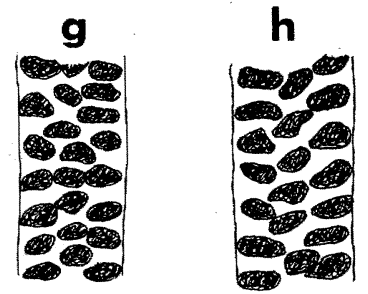

Fig. 6.-Camera lucida drawings of medulla cell patterns. The amount of pigment in medulla cells varies, all those shown here indicate dense pigmentation for clarity of illustration. a) $\mathbf{M i}$ crodipodops pallidus, b) M. megacephalus, c) Dipodomys agilis, d) D. deserti, e) D. elator, f) D. elephantinus, g) D. heermani, h) D. merriami i) D. microps, j) D. ordii, k) D. panamintinus, l) D. phillipsii, m) D. spectabilis, n) D. stephensi. Scale is $0.1 \mathrm{~mm}$ long.

Dipodomys agilis.-Medium length and width for genus ( 13.5 by $0.030-0.040$ ). Base nearly as wide as shaft; tip tapers gradually. Cross section oval. Medulla cells arranged in irregular rows of three to four rounded to flattened cells, sometimes connecting. TTU 675; Sunnymead, 2 mi N Hwy. 60, Riverside Co., California, 13 February 1959.

Dipodomys deserti.-Longest hair in family and wide for the genus (19.1 by 0.030 0.048). Base wide; shaft curved; tip tapers gradually. Cross section slightly flattened oval. Medulla cells oval to flattened; rows sometimes regular, one cell alternating with two or three cell rows. TTU 682; Mesa, Arizona, 26 July 1929.

Dipodomys elator.-Length and width medium for genus (12.5 by $0.030-0.040$ ). Base and tip curved; tip gradual. Cross section slightly irregular oval. Medulla with rows of two flattened cells across alternating with one cell in center of shaft. TTU 11,444; 3 mi N Quanah, Claude Holcomb Ranch, Hardeman Co., Texas, 1 July 1970.

Dipodomys elephantinus.-Long for genus but medium in width (14.5 by 0.030 ). Base curved, as wide as shaft; tip gradual. Cross section oval. Medulla cells flattened, some connecting; rows of two to three cells across. USNM 67,150; Bear Valley, San Benito Co., California, 20 June 1894.

FIG. 5.-Camera lucida drawings of the bases and tips of the hair of Dipodomys (A-L) and Microdipodops (M-N). A) D. agilis, B) D. deserti, C) D. elator, D) D. elephantinus, E) D. heermani, F) D. merriami, G) D. microps, H) D. ordii, I) D. panamintinus, J) D. phillipsii, K) D. spectabilis, L) D. stephensi, M) M. megacephalus, N) M. pallidus. Scale is $0.5 \mathrm{~mm}$ long. 


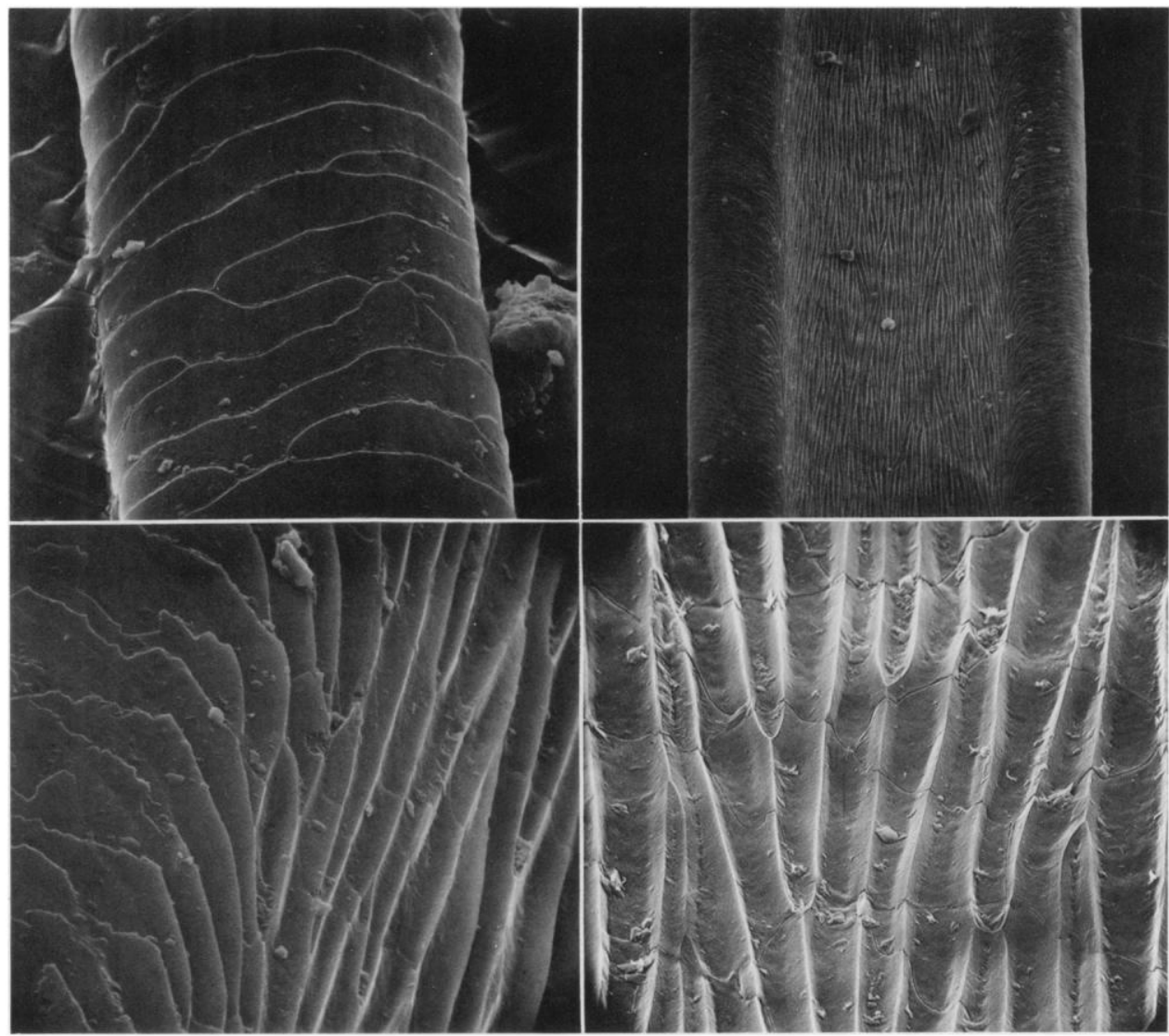

Fig. 7.-Upper left, typical Dipodomys phillipsii overhair (hair approximately $0.35 \mathrm{~mm}$ wide) indicating imbricate scale pattern. Upper right, SEM photograph of Liomys irroratus overhair (hair approximately $.330 \mathrm{~mm}$ wide) illustrating the wide trough, often visible without the aid of a microscope. Note the apparent difference in scale pattern from trough to ridges. Lower left, SEM photograph of Liomys pictus trough hair at the junction of the ridge (left) and trough (right). The horizontal scale pattern of the ridges tends to dip down and become obscured. However, several roughly horizontal lines can be seen on the right half of the picture. See below for further explanation. Lower right, Liomys salvini trough hair. The strong vertical lines indicate the coarse cortical cells underlying the thinner and roughly horizontal cuticular scales. At this magnification the cuticular scales become obvious and indicate the same basic flattened, imbricate pattern of the overhair of other members of the family.

Dipodomys heermani.-Medium length and width for genus (12.2 by $0.030-0.040$ ). Base curved and wide; shaft and tip straight. Cross section regularly oval. Medulla cells oval, three across; rows regular. USNM 127,790; Tejon Canyon, California, 15 July 1903.

Dipodomys merriami.-Medium in length but wide for genus ( 13.6 by $0.040-0.047$ ). Shaft wider than slender base; tip gradual, slightly curved. Cross section oval. Medulla cells irregular in shape; pattern of two cells across shaft alternating with one cell (as in five spots on a die). TTU 11,617; 1 mi N Portal, Chiricahua Mtns., Cochise Co., Arizona, 20 July 1970.

Dipodomys microps.-Medium in length and width for genus ( 13.5 by $0.030-0.040)$. Base and shaft narrow, curved; tip tapers gradually. Cross section oval. Medulla cells 
generally rounded; pattern regular with two cells alternating with one cell (see above). TTU 28,511; Spanish Springs Road, N Sparks, Washoe Co., Nevada, 11 April 1971.

Dipodomys ordii.-Very short but widest for genus, (11.3 by 0.030-0.050). Base shaft and tip usually straight or only slightly curved; tip tapers gradually. Cross section oval. Medulla cells irregular in shape; three to four cells across; rows irregular. TTU 4831; Nebraska National Forest, Bessy Division, Thomas Co., Nebraska, 15 August 1967.

Dipodomys panamintinus.-Length short to medium and medium width (12.6 by 0.030). Base wide; shaft and tip straight; tip gradual. Cross section oval. Medulla cells oval to flattened; cells in regular rows of two or three cells across alternating with one cell. TTU 24,512; 4 mi N Sparks, W side Spanish Springs Valley, Washoe Co., Nevada, 28 April 1974.

Dipodomys phillipsii.-One of two shortest for genus but medium in width (11.1 by $0.030-0.040$ ). Base and shaft slightly curved; tip gradual. Cross section oval. Medulla cells rounded to oval; rows often irregular, two or three cells across. USNM 91,944; Valparaiso, Zacatecas, Mexico, 17 December 1897.

Dipodomys spectabilis.-Long for genus and relatively wide (15.3 by $0.035-0.045$ ). Base wide; shaft and tip slightly curved; tip tapers gradually. Cross section rounded rather than oval. Medulla cells oval to flattened or irregular in shape; pattern slightly irregular with two to three cells across shaft. TTU 7523; 5 mi NE Penwell, Ector Co., Texas, 11 August 1968.

Dipodomys stephensi.-One of the shortest and the narrowest for genus (11.1 by 0.020-0.030). Base narrow; shaft curved; tip gradual in taper. Cross section slightly irregular oval. Medulla cells oval or rounded; pattern generally regular with one or two cells across shaft. USNM 160,087; Banning, California, 20 June 1909.

\section{Subfamily Heteromyinae}

In contrast to the previous groups, the subfamily Heteromyinae appears to have three general types of hair-1) the wide, troughed overhairs; 2) relatively long and wide, but untroughed overhairs; and 3) fine, slightly wavy underfur similar to that of the Perognathinae and Dipodomyinae. Occasionally the second type of overhair shows a very weakly developed trough. In Liomys salvini the second type of overhair shows a peculiar modification-these hairs are bent at nearly right angles to the back of the animal so that the tip protrudes above the other hairs of the body.

Scale pattern is similar in general to other heteromyids except in the trough. The scales appear to curve downward over the ridges into the trough where the predominant pattern is longitudinal rather than horizontal. Upon closer examination with the SEM the typical crenate, flattened scales can be recognized. The distortion of the cuticular scales in the trough is probably due to the coarsely sculptured fusiform cortical cells just beneath the cuticle (see Figs. 4 lower left; 7 upper right, lower left, lower right and Fig. 10). The ventral surface of the trough hairs have a normal crenate scale pattern.

\section{Genus Liomys}

Lengths are average for the family but hairs are very wide. Bases are narrow but flare rapidly to broad-bladed shafts; tips taper abruptly as in Chaetodipus. A trough is prominent on the dorsal surface of the hair, but it varies in width and depth. The medulla appears to extend across the trough, but pigment is restricted to ridges in densely packed cells. See Figs. 7-9 and Table 1 .

Liomys irroratus.- - Long for genus and medium to wide (12.3 by 0.33 ). Base narrow, flares rapidly; widest part of hair in basal fourth of broad shaft; tip tapers abruptly. Cross section shows wide, relatively deep trough; ventral surface domed but tends to flatten out near ridges. Medulla complex; cells oval to flattened and compressed to- 


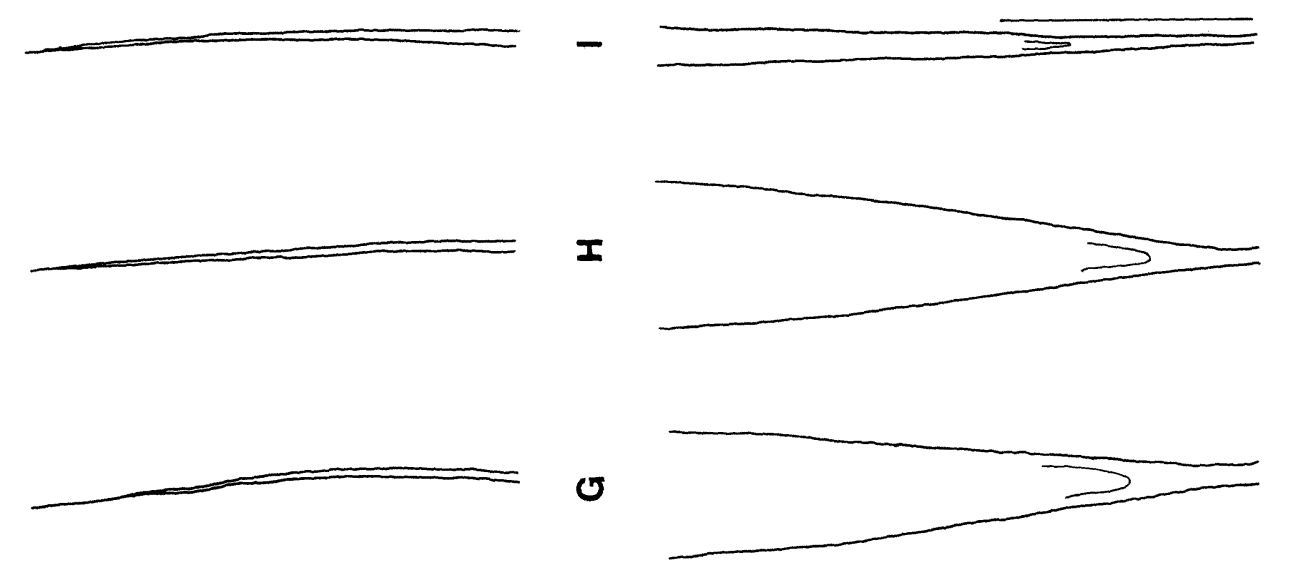

山 5

U1

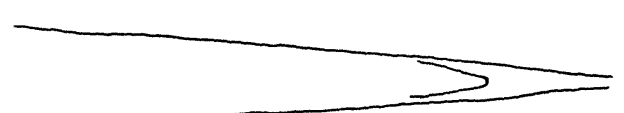

口

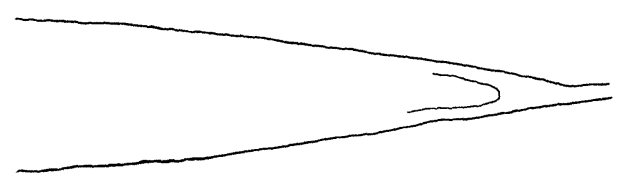

$u$

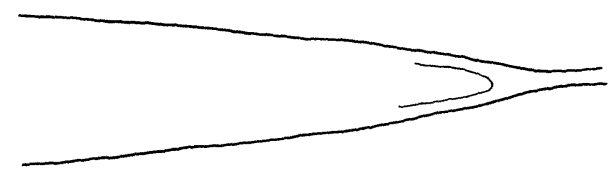

$\boldsymbol{m}$

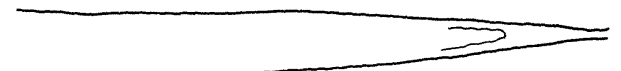

$\varangle$

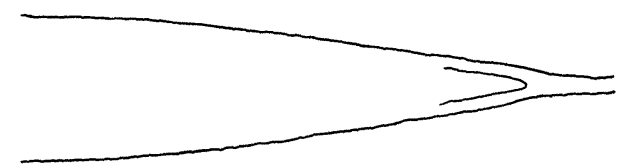




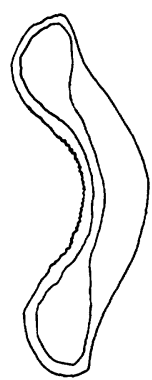

$\mathbf{1}$

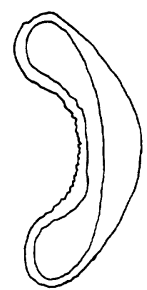

2

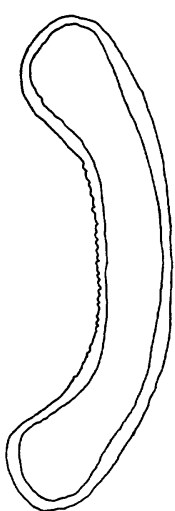

3

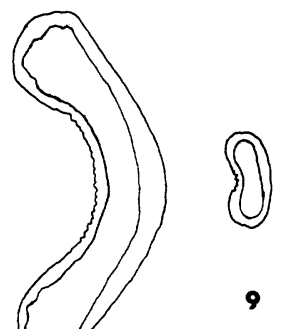

5

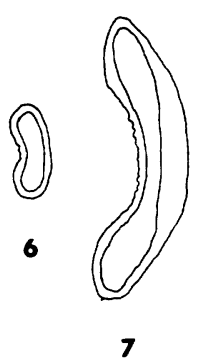

7

8

FIG. 9.-Camera lucida drawings of hair cross sections. The outline represents the cuticle, the space between the two lines, the cortex, and the inner line the medulla boundary. 1) Liomys irroratus, 2) L. pictus, 3) L. salvini, 4) Heteromys anomalus, 5) H. australis, 6) H. desmarestianus, 7) $\mathrm{H}$. gaumeri, 8) H. longicaudatus, 9) $\mathrm{H}$. nelsoni. Scale is $0.1 \mathrm{~mm}$ long.

gether along ridges. Pigment restricted to medulla in ridges and distal third of the hair; no pigment seen in trough. USNM 78,945; Silao, Guanajuato, Mexico, 19 June 1896. The hair of this species was figured and briefly discussed by Short (1978).

Liomys pictus.-Short hair and narrow for genus (9.9 by $0.19-0.25$ ). Base narrow; shaft flares but not as much as irroratus; tip tapers more gradually. Trough in cross section deep; ridges rounded; ventral hair surface is slightly rounded. Medulla not obvious; pigment restricted to ridges. USNM 91,340; Santiago, Nayarit, Mexico, 20 June 1897.

Liomys salvini.-Medium in length but widest for genus (11.6 by $0.35-0.38$ ). Base narrow, flares rapidly to very broad shaft; tip tapers abruptly. Cross section indicates wide, shallow trough; ventral hair surface rounded, flattened near ridges. Medulla complex; cells compressed in ridges.

FIG. 8.-Camera lucida drawings of the bases and tips of overhair of Liomys (A-C), and Heteromys (D-I). A) L. irroratus, B) L. pictus, C) L. salvini, D) H. anomalus, E) H. australis, F) $H$. desmarestianus, G) H. gaumeri, H) H. longicaudatus, I) H. nelsoni. Scale is $0.5 \mathrm{~mm}$ long. 


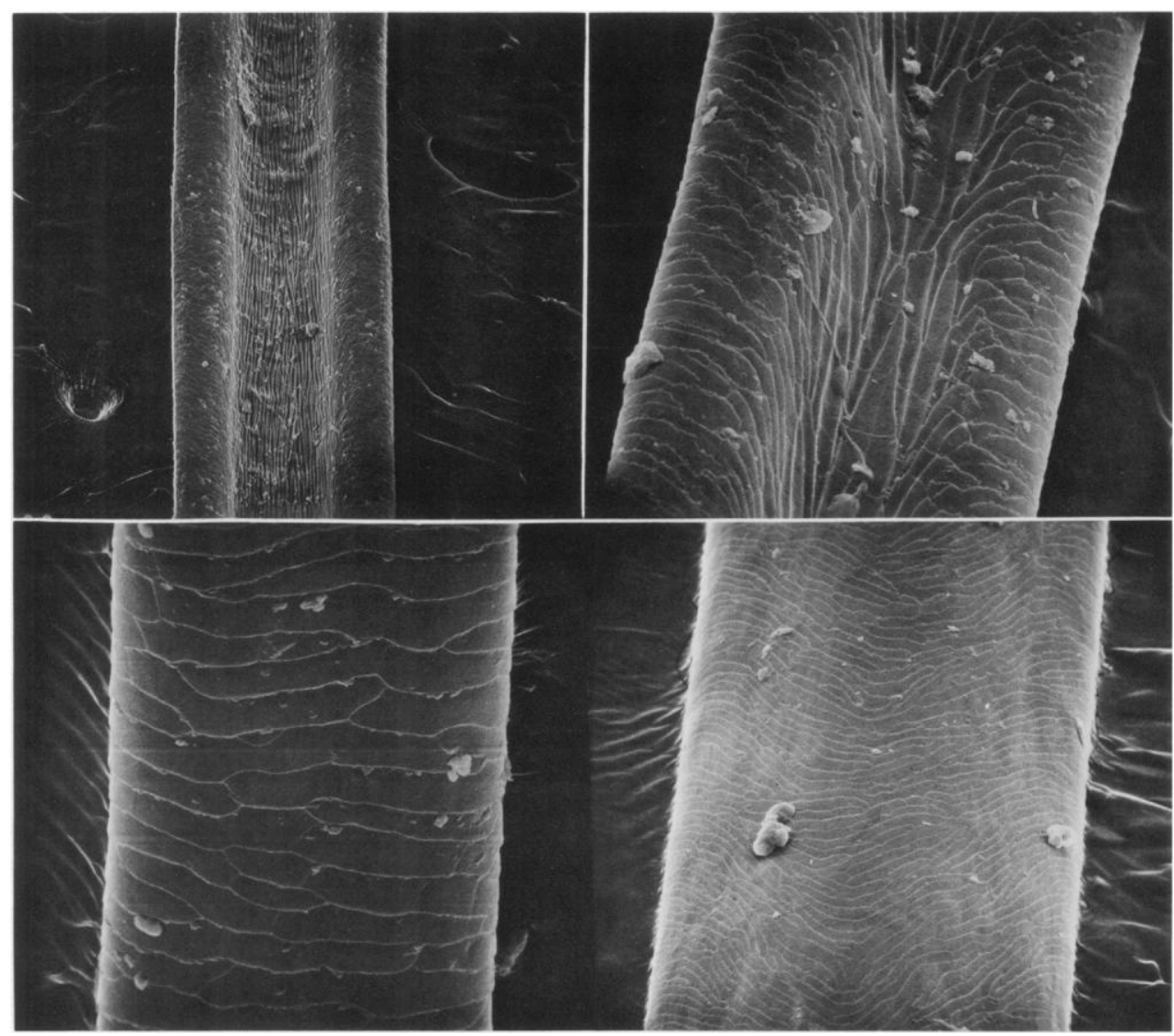

FIG. 10.-Upper left, SEM photograph of an overhair of Heteromys gaumeri (hair approximately $.300 \mathrm{~mm}$ wide) showing narrow trough and peculiar scale pattern in trough. Upper right, SEM photograph of $\boldsymbol{H}$. longicaudatus overhair (hair approximately $.330 \mathrm{~mm}$ wide) indicating a very weakly developed trough with an intermediate scale pattern. Lower left, $H$. nelsoni small overhair (hair approximately $.090 \mathrm{~mm}$ wide) without trough showing scale pattern typical for family. Lower right, ventral side of wide troughed hair of $\mathrm{H}$. anomalus (hair approximately .325 mm wide).

A second type of overhair, mentioned above, can be seen protruding from the back of an individual of this species, giving the animal a "fuzzy" appearance. Upon examination these hairs are found to be bent at nearly a right angle, the distal half of the hair pointing out, perpendicular to the plane of the back. Cross sections of the basal portion, bend area, and distal shaft reveal rounded, oval, and flattened oval shapes, respectively. Upon examination with the SEM, no indication of a trough was found; scale pattern is similar to that of other members of the family (especially $P e$ rognathus and Dipodomys). USNM 332,442; Corpus Christi, Chiltepe, Nicaragua, 6 September 1962.

\section{Genus Heteromys}

General form is similar in all respects to Liomys except tips taper gradually in Heteromys. Troughs are present in all species, but are developed to varying degrees. In addition to the broad-bladed trough hairs of the Heteromyinae, narrower overhairs 
were also studied. These possess a poorly developed trough within which the longitudinal cortical cell pattern is developed to varying degrees. It is, however, generally better developed than in the smaller overhairs of Liomys. Several of these narrow overhairs were sectioned and revealed oval cross sections with only a slight indication of a trough (Figs. 8-10 and Table 1).

Heteromys anomalus.-Medium length for genus but relatively wide ( 11.7 by 0.30 0.35). Base narrow, flares rapidly to broad shaft; tip tapers rather gradually. Cross section indicates broad, shallow trough; ventral hair surface rounded, flattens slightly toward ridges. Medulla cells and pigment restricted to ridges. USNM 143,795; San Julian, Venezuela, 7 August 1900.

Heteromys australis.-Shortest for genus and medium in width (9.4 by 0.19-0.26). Base narrow, flare is not as obvious as in some species; shaft moderately wide; tip narrows gradually. Cross section reveals deep trough; ventral surface of hair very rounded. Medulla cells not distinct, packed in ridges of shaft. USNM 113,304; San Javier, N Ecuador, 26 May 1900.

Heteromys desmarestianus.-Medium length but very narrow for genus (11.0 by $0.12-0.16$ ). Base and shaft not distinct due to narrowness of hair; tip tapers gradually to a fine point. Cross section shows very narrow trough, but ridges are wide and rounded as is ventral hair surface. Medulla packed with pigmented cells which extend across trough in tight masses. Pigment granules present in cortex. USNM 179,007; Mt. Pirri, 5,200 ft., Panama, 19 April 1912.

Heteromys gaumeri.-Longest and widest for genus (13.3 by $0.26-0.27)$. Base widens rapidly to broad shaft; tip gradual. Trough in cross section wide and relatively deep; ventral hair surface domed but flattens near ridges. Medulla cells restricted to ridges in compact masses. USNM 249,862; El Satz, Peten, Guatemala, 23 January 1919.

Heteromys longicaudatus.-Medium length but widest for genus (11.9 by 0.31 0.36). Base flares to very broad shaft; tip tapers gradually. Cross section shows very wide, deep trough; ventral surface rounded but flattens near ridges. Medulla cells packed in ridges. USNM 100,211; Montichristo, Tabasco, Mexico, 4 May 1900.

Heteromys nelsoni.-Long but narrowest for genus (12.2 by $0.10-0.12$ ). Base indistinct from narrow shaft. Trough shallow and narrow, not well developed. Ventral surface of hair slightly flattened; ridges rounded. Medulla cells packed across hair in dense masses. USNM 77,578; Pinabete, Chiapas, Mexico, 11 February 1896.

\section{Discussion}

The overhair of heteromyid rodents apparently falls into two broad morphological types-non-troughed hairs and troughed hairs. Because these types of hairs follow closely current taxonomic arrangements, it is tempting to believe that they may give a clue to the evolutionary history of this group. Our hair samples of most perognathines, and those of all members of the genera Dipodomys and Microdipodops are of the non-troughed type. All chaetodipines and heteromyines have troughed hairs. The troughed hairs of Liomys and Heteromys evidently are more specialized than those of the subgenus Chaetodipus with the cuticular pattern in the trough being modified from other portions of the hair. In members of subgenus Chaetodipus, the cuticular pattern in the trough does not differ from the remainder of the hair. The exact meaning of the troughed hairs of Perognathus amplus and P. formosus in the subgenus Perognathus is somewhat obscure. We do not believe that these species are classified in the wrong subgenus. The hair of these animals does form a nice transition from the hair of the subgenus Perognathus to that of Chaetodipus and may indicate the past course of evolution in the genus. 
Based upon characteristics of the hair, it would appear that the perognathines, $D i$ podomys, and Microdipodops would form one evolutionary lineage within the Heteromyidae and the chaetodipines, Liomys, and Heteromys would form another, with the members of the genus Perognathus being ancestral to both. However, when viewed in the light of other morphological and paleontological evidence (Wood, 1935; Lindsay, 1972; Hafner, 1978) these relationships seem impossible. Evidence presented by these and other authors indicate that the three currently recognized subfamilies arose independently from an ancestral form.

If these evolutionary relationships are correct, it would indicate that one of the hair types observed in the family Heteromyidae has arisen at least twice. If, on the one hand, the non-trough hair is the ancestral character state, then the trough hair has arisen independently in the Perognathinae and Heteromyinae; on the other hand, if the trough hair is the primitive character, then the non-trough hair has arisen independently in the Perognathinae and Dipodomyinae. These results should not have been totally unexpected because as pointed out by Wood (1935) "parallelism is the evolutionary motto of rodents in general and of the heteromyids in particular. This extends to all parts of the body." It appears that the hair has not escaped this parallel development.

Although we cannot definitely determine which of the hair types is derived, in our opinion it is the trough type. The non-trough type of hair is possessed by a wide variety of rodent species (Short, 1978). Also, the trough type of hair possessed by the perognathines and heteromyines, although similar, are distinct. This indicates to us that this type of hair could have developed independently in the two groups.

There has been considerable controversy over the subfamilial placement of members of the genus Microdipodops. Our data can shed no light on this problem. However, if Hafner's (1978) placement of them in the Perognathinae is correct, our data would support his allying them with the silky pocket mice of the subgenus Perognathus. Wood (1935) believed that within the Heteromyidae that "the Heteromyinae are more distinct than are the other two groups." The hair morphology would seem to support this statement. The hair of Liomys and Heteromys are more modified from what we believe to be the primitive hair type than are any other members of the family.

Although the hair of individual species can be characterized with detailed study, we do not believe that hair structure will be of value in evolutionary studies of this group below the generic or subgeneric level. We agree with the conclusion of Short (1978) that the cuticular scale patterns on the hairs are inadequate for distinguishing between species of mammals. However, with a suite of characters, as he pointed out, the species can be characterized and distinguished.

As stated earlier, the hair of mammals serves an extremely important thermoregulatory function. The exact function served by the troughing in the hair of some members of this family can only be hypothesized at this time. One possible explanation, which should be investigated, is that the overlapping of these numerous hairs with a trough may increase the amount of "dead" air space trapped by the hair. This could increase the insulation efficiency of the hair and could help reduce cutaneous water loss.

\section{ACKNOWLEDGMENTS}

Money for the use of the scanning electron microscope in this study was provided by a grant from The Graduate School, Texas Tech University, Dr. J. Knox Jones, Jr., Dean. We gratefully acknowledge Dr. Robert J. Baker and Dr. Jerry D. Berlin for allowing us to use their microscopes and other research facilities. Mr. Franklin Bailey, Biology Technician, took the scanning electron photographs. We wish to thank Robert 
Fisher for collecting hair from specimens at the National Museum of Natural History, William Bleier for assistance with embedding and sectioning techniques, Christyna Laubach for translation of articles written in Polish, and Tony Mollhagen for editorial assistance.

\section{LITERATURE Cited}

Anderson, C. A., AND J. D. Lyeder. 1971. Substructure of wood cortical cells. Australian J. Biol. Sci., 24:1355-1357.

ANDERson, C. A., AND M. Lipson. 1970. Scanning electron microscopy of fiber cross sections. Text. Res. J., 40:88-90.

APPleyaRD, H. M., AND A. B. Wildman. 1969. Fibres of archaeological interest: their examination and identification. Pp. 624-633, in Science in archaeology (D. Brothwell and E. Higgs, eds.), Thames and Hudson, Bristol, second ed., $720 \mathrm{pp}$.

Azzola, F. K., AND M. Shurmann. 1969. Elektronenmikroskopische Untersuchung der Oberflachenstruktur von Wollfasern nach Polymerenbelegung zur Antifilzausrustung und ihre Veranderung durch Waschen. Melliand Textilib., 50:187-193.

Benedict, F. A. 1957. Hair structure as a generic character in bats. Univ. California Publ. Zool., 59:285-548.

Bradbury, J. H., AND J. D. Leeder. 1970. Keratin fibres. IV. Structure of the cuticle. Australian J. Biol. Sci., 23:843-854.

Bradbury, J. H., AND J. M. O'Shea. 1969. Keratin fibres, II. Separation and analysis of medullary cells. Australian J. Biol. Sci., 22:1205-1215.

BurT, W. H. 1936. A study of the baculum in the genera Perognathus and Dipodomys. J. Mamm., 17:145-156.

Carpenter, R. E. 1966. A comparison of thermoregulation and water metabolism in the kangaroo rats Dipodomys agilis and Dipodomys merriami. Univ. California Publ. Zool., $78: 1-36$.

Chapman, G. V., and J. H. Bradbury. 1968. The chemical composition of wool. 7. Separation and analysis of orthocortex and paracortex. Arch. Biochem. Biophys., 127:157163.

COLE, H. I. 1924. Taxonomic value of hair in Chiroptera. Phillipine J. Sci., 14:117-121.

DAY, M. G. 1966. Identification of hair and feather remains in the gut and faeces of stoats and weasels. J. Zool., 148:201-217.

- 1968. Food habits of British stoate (Mustela erminea) and weasels (Mustela $n i$ valis). J. Zool., 155:485-497.

DEARBORN, N. 1939. Use of sections in identifying hair. J. Mamm., 20:346-348.

Douglas, C. L. 1965. Biological techniques in archaeology. Amer. Antiquity, 31(No. 2, Pt. 2):193-201.

Genoways, H. H. 1973. Systematics and evolutionary relationships of spiny pocket mice, genus Liomys. Spec. Publ. Mus., Texas Tech Univ., 5:1-368.

GHOBRLAL, L. I. 1970. A comparative study of the integument of the camel, Dorcas gazelle and jerboa in relation to desert life. J. Zool., 160:509-521.

Goldman, E. A. 1911. Revision of the spiny pocket mice (genera Heteromys and Liomys). N. Amer. Fauna, 34:1-70.

HAFNER, J. C. 1978. Evolutionary relationships of kangaroo mice, genus Microdipodops. J. Mamm., 59:354-365.

HAITLINGER, R. 1967. Structure of medulla and cortical substance of the hair in native representatives of the genus Apodemus Kaup, 1829. Przeglad Zoologiczny, 11(4):434441.

HALL, E. R. 1941. Revision of the rodent genus Microdipodops. Field Mus. Nat. Hist., Zool. Ser., 27:233-277.

Hall, E. R., and K. R. Kelson. 1959. The mammals of North America. Ronald Press Co., New York, 1:xxx + 1-546 + 79 .

Haly, A. R., J. W. SNaIth, AND C. A. ANDERSON. 1970. Scanning electron microscopy of the cortex and cuticle of wool and hair fibers. Text. Res. J., 40:1126-1128.

Hausman, L. A. 1920. Structural characteristics of the hair of mammals. Amer. Nat., 54:496-523.

1930. Recent studies of hair structure relationships. Sci. Monthly, 30:258-277.

1932. The cortical fusi of mammalian hair shafts. Amer. Nat., 66:461-470.

1944. Applied microscopy of hair. Sci. Monthly, 59:195-202.

HerRINGTON, L. P. 1951. The role of the piliary system in mammals and its relation to the thermal environment. Ann. New York Acad. Sci., 53:600-607.

JoHnSON, D. J., AND P. T. SPEAKMAN. 1965. Ultrafine structure of $a$-keratin. Nature, 205:268.

KING, N. L. R., AND J. H. BRAdbury. 1968. The chemical composition of wool. V. The epicuticle. Australian J. Biol. Sci., 21:375384.

Kozhukovskaya, A. F. 1969. The comparison of hair structure in some species of the subfamily Microtinae. Leningrad. Universitet. Vestnik. Seriya Biologu, 24(4):42-50 (in Russian).

LACKEY, J. A. 1967. Biosystematics of heermanni group of kangaroo rats in southern California. Trans. San Diego Soc. Nat. Hist., $14: 313-344$. 
Leeder, J. D., and J. H. Bradbury. 1968. Conformation of epicuticle on keratin fibers. Nature, 218:694-695.

LIDICKER, W. Z., JR. 1962. The nature of subspecies boundaries in a desert rodent and its implications for subspecies in taxonomy. Syst. Zool., 11:160-171.

LiNDSAY, E. H. 1972. Small mammal fossils from the Barstow Formation, California. Univ. California Publ., Geol. Sci., 93:1-104.

LUNDGREN, H. P., AND W. H. WARD. 1963. The keratins. Pp. 39-122, in Ultrastructure of protein fibers (R. Borasky, ed.), Academic Press, New York, xvii + 185 pp.

MathiaK, H. A. 1938. A key to hairs of the mammals of southern Michigan. J. Wildlife Mgmt., 2:251-268.

MAYER, W. V. 1952. The hair of California mammals with keys to the dorsal guard hairs of California mammals. Amer. Midland Nat., 48:480-512.

MiLES, W. B. 1965. Studies of the cuticular structure of the hairs of Kansas bats. Search, 5: 48-50.

Moore, T. D., L. E. Spence, AND C. E. DugNOLLE. 1974. Identification of the dorsal guard hairs of some mammals of Wyoming. Bull. Wyoming Game and Fish Dept., 14:x + 1-177.

NASON, E. S. 1948. Morphology of hair of eastern North American bats. Amer. Midland Nat., 39:345-361.

NoBACK, C. R. 1951. Morphology and phylogeny of hair. Ann. New York Acad. Sci., 53:476-492.

PATton, J. L. 1967a. Chromosome studies of certain pocket mice, genus Perognathus (Rodentia: Heteromyidae). J. Mamm., 48:27-37. - 1967b. Chromosomes and evolutionary trends in the pocket mouse subgenus $P e$ rognathus (Rodentia: Heteromyidae). Southwestern Nat., 12:429-438.

The Museum, Texas Tech University, Lubbock, Texas 79409, and Section of Mammals, Carnegie Museum of Natural History, 4400 Forbes Avenue, Pittsburgh, Pennsylvania 15213. Submitted 11 December 1977. Accepted 15 April 1978.
ROGERS, G. E. 1959a. Electron microscopy of wool. J. Ultrastr. Res., 2:309-330.

$1959 \mathrm{~b}$. Electron microscope studies of hair and wool. Ann. New York Acad. Sci., 83:378-399.

RUDALL, K. M. 1941. The structure of the hair cuticle. Proc. Leeds Phil. Soc., 4:13-18.

SHORT, H. L. 1978. Analysis of cuticular scales on hairs using the scanning electron microscope. J. Mamm., 59:261-268.

SPURR, A. R. 1969. A low viscosity epoxy resin embedding medium for electron microscopy. J. Ultrastr. Res., 26:31-43.

STAINS, H. J. 1958. Field guide to guard hairs of middle-western furbearers. J. Wildlife Mgmt., 22:95-97.

STOCK, A. D. 1974. Chromosome evolution in the genus Dipodomys and its taxonomic and phylogenetic implications. J. Mamm., 55:505526.

Stoves, J. L. 1942. The histology of mammalian hair. Analyst, 67:385-387.

1944. The appearance in cross section of hairs of some carnivores and rodents. Proc. Roy. Soc. Edinburgh, B, 112:99-104.

TOLDT, K. 1935. Aufbau und naturliche Farbung Haarkleides der Wildsaugetiere. Verlag: Deutsche Gesellschaft fur Lleintierund Peiztierzucht, B. m. b. H. \& Co., Leipzig, xii $+291 \mathrm{pp}$.

WEINGART, E. L. 1973. A simple technique for revealing hair scale patterns. Amer. Midland Nat., 90:508-509.

Williams, C. S. 1938. Aids to the identification of mole and shrew hairs with general comments on hair structure and hair determination. J. Wildlife Mgmt., 2:239-250.

WooD, A. E. 1935. Evolution and relationship of the heteromyid rodents, with new forms from the Tertiary of western North America. Ann. Carnegie Mus., 24:73-262. 